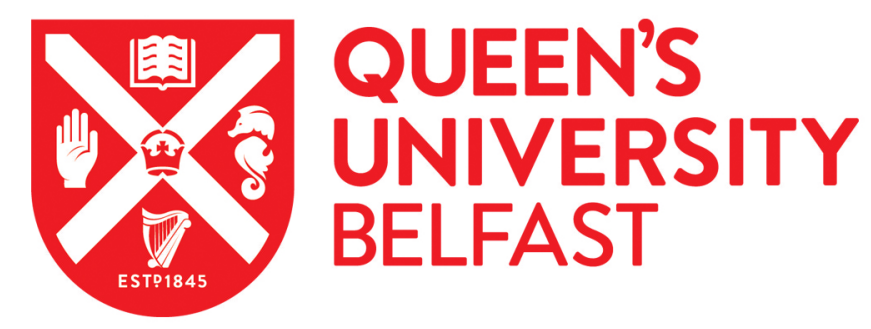

\title{
The First Garden City? Environment and utopianism in an Edwardian institution for the insane poor
}

Allmond, G. (2017). The First Garden City? Environment and utopianism in an Edwardian institution for the insane poor. Journal of Historical Geography, 56(Jan), 101-112. https://doi.org/10.1016/j.jhg.2017.03.004

Published in:

Journal of Historical Geography

Document Version:

Peer reviewed version

Queen's University Belfast - Research Portal:

Link to publication record in Queen's University Belfast Research Portal

Publisher rights

(c) 2017 Elsevier Ltd. This manuscript version is made available under the CC-BY-NC-ND 4.0 license http://creativecommons.org/licenses/by$\mathrm{nc}-\mathrm{nd} / 4.0 /$ which permits distribution and reproduction for non-commercial purposes, provided the author and source are cited.

\section{General rights}

Copyright for the publications made accessible via the Queen's University Belfast Research Portal is retained by the author(s) and / or other copyright owners and it is a condition of accessing these publications that users recognise and abide by the legal requirements associated with these rights.

Take down policy

The Research Portal is Queen's institutional repository that provides access to Queen's research output. Every effort has been made to ensure that content in the Research Portal does not infringe any person's rights, or applicable UK laws. If you discover content in the Research Portal that you believe breaches copyright or violates any law, please contact openaccess@qub.ac.uk. 


\begin{abstract}
At Kingseat Asylum near Aberdeen, in 1901-1904, asylum authorities constructed an asylum which appears to resemble Ebenezer Howard's schematic diagram of a garden city 'ward'. Using theories of the relationship between spatial rationalities and governmentality, this paper asks whether Howard's garden city could plausibly have been a model for the Kingseat Asylum layout. The historiographical orthodoxy, which claims that late nineteenth-century asylums were little more than 'warehouses' to sequester the unwanted, is problematized and the existence is postulated of a distinct Scottish asylum culture which was alarmed by the tendency to asylum growth, overcrowding and disease in England and elsewhere. Garden city reformers and asylum builders faced similar problems in terms of overcrowding and disease, and were both concerned about the 'aggregation' of the poor and their consequent loss of individuality. By the beginning of the twentieth century, Scottish asylum builders, in particular, rejected the increasingly large monolithic style of asylum in favour of dispersed 'village' style settlements. Aberdeen asylum authorities may have sought to access the symbolic resonance of the garden city layout and its utopian qualities as a 'marriage' of town and country, health and industry, variety and uniformity. The garden city asylum also points to a spectrum of opinion relating to the therapeutic role of environment in relation to mental illness and suggests that 'hard hereditarian' approaches were less influential, at least in Scotland, than is sometimes claimed.
\end{abstract}

Keywords: garden city, village asylum, environment, individuality, madness, governmentality

Abbreviated article title: The First Garden City? Kingseat Asylum, Aberdeen

\title{
List of Figures:
}

Figure 1 - Howard's Diagram No 3. Source: E. Howard, To-morrow: A Peaceful Path to Real Reform, London, 1898.

Figure 2 - Alt-Scherbitz asylum. Source: J. Sibbald, On the Plans of Modern Asylums for the Insane Poor, Edinburgh, 1897.

Figure 3 - Architect's plan of Kingseat Asylum dated 1906. Source: location of original unknown, reproduced from Jenkins \& Marr, Kingseat Village Proposals, Aberdeen, 1997 (unpublished report).

Figure 4 - Kingseat Asylum layout, showing resemblances to Howard's Diagram No 3. Prepared by Libby Mulqueeny of Queen’s University, Belfast. 
Figure 5 - Aerial photograph of Kingseat taken in 2001 shortly after its closure as a hospital. Published by permission of Historic Environment Scotland.

Figure 6 - Location of asylums in relation to nearest urban centre from which patients are drawn. (Distances plotted by author using Google Maps.) 
The ideal of the garden city, as advanced by Ebenezer Howard in the last decade of the nineteenth century, was immediately recognised by his contemporaries as inspirational, while often simultaneously being heavily criticised for its perceived utopianism. Typical were the comments of an early reviewer in The Scotsman, that the garden city 'no doubt seems a paradise on paper but ... also seems too good a residential quarter ever to be practically realisable'. ${ }^{1}$ Howard's persistence was nonetheless formidable and he was relatively rapidly able to muster enough support to realise a version of his vision at Letchworth. The criticisms of early doubters were rapidly forgotten as garden cities, garden suburbs and garden villages, inspired by Howard, were not only built in the U.K., U.S. and western Europe, but, as recent scholarship has shown, across the world wherever colonial influence made itself felt, in South America, Africa and the Middle and Far East. ${ }^{2}$ Indeed, Howard's vision retains its utopian resonance into the present and the garden city concept continues to be invoked as a 'practical idealist' solution to the problems of unfettered urban expansion. ${ }^{3}$

Another nineteenth-century project with its roots in utopian ideals, the asylum for the insane, has not fared so well. The gradual abandonment of the asylum project in the second half of the twentieth century has been accompanied by a historiography which paints a thoroughly dystopian picture of the accumulation of 'chronic' cases in ever larger institutions. Andrew Scull appropriated the terms 'warehouses' and 'museums of madness' to describe the vast buildings which were used to segregate society's unwanted by the end of the nineteenth century. ${ }^{4}$ Although the asylum project had begun with high hopes, it is Scull's contention, followed by the majority of scholars of madness, that by the turn of the century therapeutic pessimism prevailed, based on the Morelian theory of degeneration and a resurgence of interest in Larmarckian evolution. ${ }^{5}$ According to this reading of medical discourses, hereditary weakness was caused by the poor habits and lax morals of the degenerate; mental illness was the ultimate penalty for breaking moral and hygienic laws. Society's duty was, therefore, simply to sequester the insane to prevent reproduction of the 'unfit' in asylums built as quickly and as cheaply as decorum would allow. ${ }^{6}$ 
This paper will contend that although the asylum is readily acknowledged as a 'governable space', this is often seen, in Foucauldian terms, in relation to segregation and exclusion of various kinds and/or panoptic surveillance, models which are insufficient to account for all material and spatial practices in relation to asylum provision. ${ }^{7}$ The garden city, by contrast, has seldom been viewed as constituting subjects through a particular spatial organisation. However, it will be argued here, that in the early twentieth century, both the asylum and the garden city can be seen in terms of governmentality, with spatial arrangements and environmental qualities, elaborated through discourses of health, freedom and individuality, acting to produce social effects. ${ }^{8}$ Previous scholarship has noted both that the garden city movement was influenced by contemporary medical discourses and that the 'benevolent social and economic engineering' represented by garden cities was paralleled by the 'colony' type of institution, the most well-known example being the epileptic colony at Ewell (opened in 1904). 9 This paper will postulate the existence of a distinct Scottish asylum culture in which moral, mental and physical health was strongly linked to the qualities of environments by Scottish asylum authorities who were alarmed by the tendency to asylum growth, overcrowding and disease in England and elsewhere. It will be suggested that Ebenezer Howard's garden city, which sought to address the dangers of degeneration, overcrowding and disease represented by the urban slums, is a possible source for the layout of the asylum at Kingseat, outside Aberdeen, which strongly resembles Howard's garden city template, a resemblance which has not previously been identified in the years since its construction. ${ }^{10}$ If inspired by Howard, the asylum (opened in 1904) may have been the earliest complete expression of Howard's vision, comfortably predating Letchworth, which is usually known as the First Garden City. ${ }^{11}$ This paper will show that an idealised community combining the advantages of town and country may have had much to commend it to asylum authorities who were addressing problems related to health, both physical and mental, similar to those that the garden city sought to confront. It will be argued that it is plausible for asylum authorities to have been attracted to the utopian elements of Howard's vision as they related to health and to have attempted to access them through the close reproduction of his diagrammatic forms, although other potential sources of inspiration for the asylum at Kingseat will also be explored. Using Margot Huxley's 
notion of spatial rationalities, it will be further argued that both layouts order 'healthy bodies and moral behaviours', a 'vitalist' discourse which sought to create 'a generalized evolutionary environment through which humanity might harness nonmaterial forces leading to higher stages of development'. ${ }^{12}$

\section{EBENEZER HOWARD'S GARDEN CITY}

By the time of the publication of To-morrow: A Peaceful Path to Real Reform in early October 1898 Ebenezer Howard had presented his vision in public on numerous occasions and had arrived at a conception of the garden city which was informed by a variety of concerns, chiefly aesthetic, sanitary and socio-economic. Although a large portion of the book was devoted to discussion of the economics of funding his network of cities through the recovery of the 'unearned increment' resulting from rising land prices through 'rate-rent', far more influential for future planned settlements was Howard's spatial and aesthetic concept of the city, with low density housing situated within garden plots, the city itself characterised by plentiful open, green spaces, rationally planned so that public buildings, housing, shopping and factories occupied clear zones in an environment of the highest quality. ${ }^{13}$

In the first edition of his book, colour illustrations, drawn by Howard himself, presented a series of geometrical diagrams for his network of 'slumless, smokeless cities', that resemble somewhat the keys and levers of the typewriters that were his other obsession. ${ }^{14}$ He asks the reader to imagine a 'shape', proportioned mathematically, with a town of a thousand acres at the centre of an estate of six thousand acres. Garden City, with a population of thirty thousand, was to be circular in form, and 'six magnificent boulevards - each 120 feet wide - traverse the city from centre to circumference, dividing it into six equal parts or wards' (Figure 1). In the centre was to be a circular garden of five and a half acres in extent, surrounded by public buildings, each in its 'own ample grounds'. A public park of 145 acres encircles the garden and this is bordered by a wide glass corridor or 'Crystal Palace', which was to provide a covered walkway or winter garden in bad weather and a venue for the sale of manufactured goods. A series of avenues is arranged in concentric rings around the centre, a 'Grand Avenue' providing a further green space at the mid-way point between Central Park and the city outskirts, and houses along this 'splendid width' are 
arranged in crescents so as to provide additional space for dwellings and the visual illusion of an even greater span. At the outer ring of the town are the 'factories, warehouses, dairies, markets, coal yards, timber yards etc.' which face a circular railway connected to the main line by means of sidings. Between local and main lines is an area devoted to dairy farms and allotments, while the rural areas between cities are to be given over to farms, forests, reservoirs and a large variety of institutions (Howard labels ten) ranging from epileptic farms to childrens' cottage homes and the insane asylum. ${ }^{15}$ Howard acknowledged his debt to, among others, James Silk Buckingham, whose unbuilt utopian scheme, known as Victoria, is characterised by Huxley as 'dispositional', with the drawing of boundaries and grids acting to classify and fix in space persons and objects 'problematized as chaotic and uncontrolled'. Spatial rationality here acts specifically on disordered states - principally those associated with poverty, such as debauchery, drunkenness and idleness - to neutralise them through the creation of order. Core to this is the creation of restrictive rules, prescriptions for aspects of social life and organisation, and the policing of spaces through surveillance. Howard's garden city appears to spatially echo this dispositional 'type', but, as we shall see, Howard and the garden city movement gradually withdrew from its disciplinary implications.

After the initial reviews, press coverage of Howard's ideas subsided until the formation of the Garden City Association (GCA) on $10^{\text {th }}$ June 1899 , eight months after the publication of To-morrow. From this point on interest built, as the garden city dreamer began to increasingly appear the practical man. The first three thousand copies had sold out by October 1901, and in June 1902 the book was reissued under its better-known title Garden Cities of To-morrow as Howard's plans to establish a real garden city were well under way. ${ }^{16}$ However, the second edition reduced the number and centrality of Howard's schematics, captioning them as 'diagrams only' and asserting that the 'plan must depend on site selected'. ${ }^{17}$ This instruction appears to be a rather terse summary of Howard's proof amendments, which muse that what he is providing is 'A diagram, not a map. A sketch, not a filled-in picture. A suggestion of possibilities, not a mould into which Society is to be run' ${ }^{18}$ These comments 
demonstrate an increasing sense that the form of his garden city should be wedded to freedom and individuality.

When Letchworth came to be built it was with a 'loose and informal aspect'. The greatest imperative was to avoid the monotony of the standard ladder rows of by-law housing that was so deprecated by contemporary reformers, not only for their ugliness but also for their consequent effect on cleanliness and morals:

'how hard it is to make a home of a dwelling exactly like a hundred other dwellings, how often it is the dullness of the street which encourages carelessness of dirt and resort to excitement ... it is the mean house and the mean street which prepare the way for poverty and vice.'19

In Huxley's terms, a 'dispositional' spatial rationality which produced docile subjects through ordered arrangements that would 'foster correct comportments' was ultimately rejected by the garden city movement as productive of the very moral problems that it was intended to combat. The kind of disciplinary structure that was entailed by Howard's strict diagrammatic forms thereby gave way to a 'generative' spatial rationality in which the quality of the environment in a broad sense, rather than the hierarchical, grid-like arrangements of buildings and streets, was intended to bring about moral and physical health. ${ }^{20}$ It was in this sense that the garden city had much in common with the late nineteenth-century asylum project in Scotland.

\section{KINGSEAT ASYLUM FOR THE INSANE POOR}

The new asylum at Kingseat, nine and a half miles north of Aberdeen, was built as the result of an enquiry into the increase of lunacy in the northeast of Scotland in 1898. A decision was taken to create a separate District Lunacy Board for Aberdeen and build a public asylum for the city for the first time, institutional care for the insane having hitherto been provided by the charitable Royal Asylum and supplemented by local poorhouses and a limited amount of 'boarding out' in the community. The Aberdeen architect Alexander Marshall Mackenzie was appointed in November 1899 and a deputation from the Aberdeen City District Lunacy Board (ACDLB) travelled with the 
architect to asylums in Scotland, England, Germany and France. They concluded that the new asylum would follow the model of Alt-Scherbitz, a Prussian asylum which was a pioneer of the 'segregate type' in which patient accommodation was dispersed into separate villa buildings rather than a single monolithic structure (Figure 2). ${ }^{21}$

The details of the decision making process with regard to the planning of Kingseat is unclear, as early records are no longer extant. ${ }^{22}$ What is known is that the asylum builders, the architect and many of those influential in public health in Aberdeen were likely to have been exposed to Howard's ideas. The Aberdeen People's Journal reviewed To-morrow, in an extensive two-part piece, a matter of weeks after the establishment of the Garden City Association in 1899, and before the appointment of Marshall Mackenzie. ${ }^{23}$ The paper reprinted extracts from the book, urging readers to buy it and noting that the Garden City Association was 'progressing in numbers and influence'. ${ }^{24}$ Likely to have been much more directly influential, however, was the Annual Congress of the Royal Institute of Public Health which took place in Aberdeen from $2^{\text {nd }}$ to $7^{\text {th }}$ August 1900, attracting eight hundred delegates from all over Britain and Ireland. The congress was attended by Marshall Mackenzie, by prominent members of the ACDLB, including the chair, and by William Reid, the medical superintendent of Aberdeen Royal Asylum. By the time the congress took place, the garden city concept had acquired considerable momentum, prompting 'a good deal of discussion' in popular, as well as more specialist, circles and it is highly likely that Howard's scheme was a topic of informal discussion among delegates. ${ }^{25}$ More specifically, a section of the congress was devoted entirely to 'Architecture and Engineering', much of it concerned with hospital construction and domestic, particularly working class, housing. Banister F. Fletcher, architect, gave a lecture speculating on the place of public health in the architecture of the coming century and justifying attention to the environment in biosocial terms. Although he did not cite Howard directly, the broader influence of Howard's ideas is apparent, since Fletcher appropriated the term 'garden cities' and suggested that well-designed streets and beautiful buildings 'help to a healthy condition of mind'. He advocated planned settlements of the 'generative' type which could provide 'the latest sanitary improvements both in the planning of the cottages and in the abundance of light and air and tasteful surroundings' and commented on 
the economics of removing factories and workers to the countryside where rents were low and health benefits high. ${ }^{26}$

By $15^{\text {th }}$ August 1900 plans for the new asylum had been prepared by Alexander Marshall Mackenzie. ${ }^{27}$ The earliest surviving architect's plan of the site, however, dates from 1906, the year that the asylum was deemed completed and all the villas were brought into use. Parallels can be traced between this plan and Howard's diagram No. 3 (Figures 3 and 4). ${ }^{28}$ The essential form of the layout in both cases is a southwest quadrant circle sector, with main axial paths converging on the public/administrative centre of the site and curved paths arranged concentrically. The asylum plan is tilted out of true north giving the main axes a similar angle to Howard's Boulevard Columbus and Boulevard Newton. The drawing is coloured in a way which suggests the 'zoning' that was also one of Howard's main contributions to town planning. A small green area corresponding to Howard's central garden is situated between stores and laundry, and the recreation ground follows the placement of Howard's Central Park. The administrative building (correlating to Howard's Town Hall) is situated in front of the recreation ground/Central Park, while the main patient accommodation is arranged either side of what may be termed the 'Grand Avenue' of the site, with the paths leading to patient villas from either side approximating the 'crescent' form of Howard's housing enclaves. The farm buildings are located at the edge of the site, together with the garden/allotments, as in Howard's plan, and the mainline railway is located just to the west of the site, curving towards the asylum in a form strikingly similar to Howard's diagram No. 2. A conservatory for cultivating flowers is located with a similar orientation to Howard's 'Crystal Palace', albeit on a smaller scale.

The most significant departure from Howard's layout is the positioning of the laundry and boiler house with its associated chimney at the apex of the site's triangular formation. Howard would certainly have placed this 'industrial' building beyond the outer ring of the site where it could easily be supplied by the railway in an efficient manner. To-morrow contains an elaborate plan for the provision of electricity by means of developing water power pumped by windmills, thus producing 'smokeless' cities, the result of which would be 'health, brightness, cleanliness and beauty'. ${ }^{29}$ Howard's primary motivation for removing factories to the edge of towns was, 
therefore, not the smoke or odours they would produce but the ease of connection with the transport network. However, in practice, this idea did not work either for Kingseat or for Letchworth. At Letchworth, the hydro-electric scheme having been dismissed, Howard was advised that the encircling of towns with industrial estates was 'not suitable in a country where the prevailing wind is from the south-west' and therefore factories should be sited in the northeast corner of any settlement. ${ }^{\circ 0}$ The motivation for siting the boiler house and laundry in the northeast corner of Kingseat, ostensibly the administrative/public centre of the site, appears to have been similar: smoke and odours would be carried away from the patient accommodation, whereas siting nearer the railway would carry the smoke over the site.

The original plan for the asylum also featured an underground tramway carrying meals from the general kitchen to dining rooms in the individual villas, 'but this system was dropped on the score of too great first cost'. ${ }^{31}$ This idea may be an echo of Howard's proposal for an 'underground railroad' to connect peripheral towns with Central City (almost certainly derived from a similar idea put forward by Buckingham). Underground trolleys to carry food were part of the American 'Kirkbride' asylum design, but although asylums such as the London County Council institution at Claybury (opened 1893) were built with walkthrough tunnels for pipework, underground food delivery was not a feature of British or Irish asylum construction. ${ }^{32}$

The same year (1906) that the plan in Figure 3 appeared, Kingseat was first referred to as a 'garden city' in the Aberdeen press, which enthused that it was 'as unlike a lunatic asylum as one could possibly imagine any place to be. No high wall, in fact, no fence of any kind, surrounds Kingseat, its outward appearance, with its finely laid out grounds, bowling greens, cricket and football pitches \&c, being more like a modern garden city' (Figure 5).33 An extensive search of the early archives relating to Ebenezer Howard and the establishment of Letchworth Garden City has given no indication, however, that either he or the GCA were aware of Kingseat. ${ }^{34}$ It is clear, however, that Howard did see the garden city as a potential response to what was perceived by contemporaries as a crisis in the growing numbers of insane. At a meeting in 1902 to discuss the 
prevention and cure of insanity, Howard suggested that the proposed garden cities would 'act indirectly as a preventive' to insanity and other diseases. 35

\section{DEGENERATION, ENVIRONMENT AND THE ASYLUM}

It is, of course, the case that 'generative' spatial rationalities, which expressly endow environments with the ability to generate health and/or virtue have a lengthy provenance. Chris Philo identifies a 'moral geography' associated with the influential Quaker asylum 'The Retreat' (opened 1796), which prioritised healthy situation, the availability of land for exercise and employment and 'retirement' from the nearest urban centre (seen as a source of 'mental disturbance') in contrast to earlier asylums whose urban sites were, like those of infirmaries, equated with better access to medical care. ${ }^{6}$ Philo suggests that the during the course of the nineteenth century a medical takeover of the asylum resulted in a blurring of boundaries between medical and moral which justified the location of asylums in rural sites on a number of grounds. These included the health of patients and the asylum as source of infection, but also a deeper cultural sense of 'moralised natural spaces' symbolising and enacting the harmonious juncture of nature and humanity. ${ }^{37}$ In Scotland the trend over time was to locate asylums ever further outside urban centres (see Figure 6, which likely underestimates this tendency as several district asylums which served rural communities were located far from urban centres and are plotted to the nearest settlement). Before the 188 os no asylum building, the striking exception being Perth District Asylum, was located more than five kilometres from the nearest urban settlement from which it drew patients. Following this, Scottish asylums that served urban areas tended to be driven further and further into the countryside. Previous scholarship has suggested that the reasons for such trends elsewhere lie in ideas of hereditarianism and the nascent pseudoscience of eugenics. It has been suggested that, in England and Wales, degenerationist thinking during the later decades of the nineteenth century led to a downgrading of the importance attributed to the environment in the treatment of mental illness. As greater importance began to be given to the inheritance of mental abnormality, previous therapeutic optimism was shaken by the belief that many patients were not susceptible to improvement and 
would remain in the asylum for life. This strand of pessimism can clearly be discerned in medical writing of the period and has been noted by numerous scholars of Victorian approaches to mental illness. $3^{8}$ For example, Matthew Jackson's study of the Sandlebridge colony for the feeble-minded, founded in Cheshire in 1902, finds that in the period up to the introduction of the Mental Deficiency Act of 1913 insanity and feeble-mindedness were increasingly attributed to hereditary rather than environmental causes. But while acknowledging the tension between hereditarian and environmentalist explanations of racial decline, Jackson emphasises that rural colonies effectively segregated 'socially dangerous defectives' in places where they could not reproduce. 39 John Radford and Deborah Park also found that custodial institutions for the mentally deficient in the U.S., Britain and Canada in this period were primarily 'manifestations of eugenically-driven social policy', the implication being that cost saving was a prime driver in the rural, colony form of institution. ${ }^{40}$ However, it is clear that in Scotland, and elsewhere, segregatory and economic impulses were wedded to a desire to provide as much agricultural land as possible for asylum patients - ideally one and a half acres per male patient by 1904, whereas in 1857 a quarter of an acre per patient had been seen as sufficient - because it afforded 'the means of healthy occupation' and of making the patients' lives more like those 'of sane persons' ${ }^{41}$ The 'hard hereditarian' approach to curbing degeneracy, by discouraging the reproduction of the 'unfit' through sterilisation or segregation and promoting the marriage of the 'fit' through legislation was little pursued by medical officials and those concerned with public health. More prevalent was a 'soft hereditarian' approach, Lamarckian in its basis, which held that environmental factors could harm the offspring of the morally weak and that in order to improve working class 'stock' reformers should address the environment and/or the personal failings of those tending to degeneracy. ${ }^{42}$

Although no asylum superintendent was appointed for Kingseat until 1903, well into the construction phase, it is very probable that, at the design stage, asylum authorities consulted the most senior psychiatric professional in Aberdeen, the superintendent of Aberdeen Royal Lunatic Asylum, William Reid. Reid was a known devotee of the most influential psychiatrist north of the border in the late nineteenth century, Sir Thomas 
factors in relation to physical and mental health at this period. ${ }^{43}$ For him, a hereditary predisposition to insanity could be counteracted by the avoidance of 'exciting' causes such as 'bad environments, bad education, bad food, bad air, unsuitable occupation, mental shocks and stress'. ${ }^{44}$ Clouston, along with many others in the medical field, persisted with the belief that poor environments which affected parents, could also affect their progeny:

'On [the] brain cells act the highest and subtlest of all forms of environment, viz., those of emotion, of passion and of beauty. No one can deny that the worst effects on the individual of certain unfavourable environments, such as bad social conditions and alcohol, are on the brain. If the securing of good environment will not only benefit the individual, which no one can deny, but will also improve posterity through the transmission of their beneficial effects, then indeed we have an argument for improved human environments which is irresistible'. ${ }^{45}$

Clouston envisaged the individual as a vitalist system possessing a finite amount of 'energy' where one organ or function could not be 'overpressed' without 'the risk of stealing energy from other organs and functions'. Surplus energy gave the brain a quality of 'resistiveness' which allowed it to combat unhealthy surroundings. On the other hand, healthy surroundings were capable of generating the vitality which was essential to mental health. Clouston saw 'Mind' as 'the highest form of energy known to us' and equated individuality with the resourcefulness that arises from vitality. ${ }^{46}$ Environment, to Clouston, signified a wide range of external influences, extending from alcohol to bad air, and it had a strong moral component. Insofar as asylum treatment was concerned, Clouston was clear that healthy and pleasant environments could be 'healing' to the insane and asylum surroundings should be clean, cheerful, bright, elegant and tasteful in order to counteract the 'tendency to degeneration in habits and ways'. ${ }^{47}$ Clouston's recurring prescription - in addition to pharmaceuticals and dietary changes - for all forms of mental illness was fresh air. Children at hereditary risk of developing insanity 'should have lots of fresh air, and ... wellventilated class-rooms ... Make them colonists, sending them back to nature'. ${ }^{48}$ 
Significantly, the signifier for Howard of health in his garden city was also fresh, pure and smoke-free air, a consequence not only of the rural situation but a product of spatial organisation, with roads 'so wide and spacious that sunlight and air may freely circulate', removing deleterious 'vitiated' air produced by the overcrowding of people. ${ }^{49}$ It is no surprise, therefore, that when a garden city for Scotland (at Rosyth) first began to be seriously proposed in 1903 , Clouston was prominent among those pushing for the adoption of Howard's principles north of the border, stating that 'there was not a doctor in Scotland who would not welcome the scheme'. ${ }^{\circ}$

Rural locations continued to hold some of the therapeutic power of an earlier period. Therefore, it is likely to be an over-simplification to attribute the impulses behind early twentieth-century asylum building entirely to economy or the impulse to sequester, although it is often suggested that faith had been lost in the ability of asylums to bring about cures by this time. Kim Ross shows that in Scotland, at least, the 'therapeutic pessimism' which, at times, can be identified in commissioners' reports seems to have given way to a renewed confidence in asylum treatment by the 1890s, one which was associated with 'improvements' including the increased differentiation of asylum spaces. ${ }^{51}$ In Foucauldian terms, the colony at Kingseat might be compared to Mettray, the French reformatory for boys, opened in 1840 and organised on colony lines with inmates divided into 'family' groups. For Foucault, Mettray was the apotheosis of the disciplinary regime, superimposing the 'coercive technologies' relating to family life, the army, the workshop and the prison within increasingly individualised spaces. ${ }^{52}$ Central to the production of subjectivity at this historical juncture, however, were additional discourses of health, vitality and individuality.

\section{HEALTH, VITALITY AND INDIVIDUALITY}

Asylum builders of the late Victorian and Edwardian periods were facing, in many ways, similar problems to those who sought to combat urban overcrowding and disease through planning and housing reform. A recurrent theme is the low mood and lack of energy of slum inhabitants, entailing a symbiotic relationship with their environment that was detrimental to mental as well as physical health. The tendency of the poor to mental ill health was, it was argued, triggered or exacerbated by poor 
environment and these poor environments were, in turn, caused by their inhabitants' degenerate practices. Mental, physical and moral health were irrevocably connected within these discourses, which were informed by a medical understanding of mental illness as broadly somatic in origin. ${ }^{53}$ While poor environments were responsible for causing disease, environmental improvements could lift up the poor from their degraded physical and mental condition. Aberdeen's ongoing attempts to clear slums and insanitary urban areas rendered the city no less subject to these discourses than Edinburgh or London. A speaker at the 1900 Congress of the Royal Institute of Public Health reported that the moral and physical health of the poor of Aberdeen was at risk due to overcrowded tenements. Councillor William Cooper, a de jure member of the ACDLB, suggested that the ideal housing scheme was that of cottages with small gardens attached in outlying districts of the city, the garden in particular being vital for 'profitable and healthy recreation' and to stimulate 'an interest in life and home'.54 By the time that Kingseat was constructed asylum authorities were also facing the endemic problems brought about by the asylum system itself. As the numbers of insane grew ever higher, existing asylum buildings which had been constructed as models of healthy and hygienic environments were extended and new asylums proliferated. Early public asylums were built for less than three hundred patients, whereas by the later decades of the nineteenth century some new English asylums were built for two thousand or more. 55 This engendered some of the very same problems that were thought to be the consequence of overcrowding in urban slums.

English lunacy commissioners' reports of the late nineteenth century are increasingly concerned with outbreaks of disease in asylum buildings, posing a threat not only to the patients themselves but to the communities within which the asylums were situated. A survey of such reports suggests that outbreaks of zymotic disease, 'asylum dysentery' and other contagious infections, were a particular source of concern from the 1890 on onwards. For example, the commissioners' report for 1896 complains of 'an unusually large number of cases of colitis, dysentery or dysenteric diarrhoea and typhoid fever ... which, in some instances, assumed an epidemic character'. ${ }^{6}$ The same report also refers continually to overcrowding and the pressure for accommodation at 
county and borough asylums which was seen as an important contributor to deaths from phthisis and pneumonia.

But it was not only overcrowding and disease that made the old-style asylums appear increasingly unattractive. Previous research has suggested that there was a strong antipathy within Scottish asylum culture to the 'aggregation' of large numbers of patients, and that large, 'barrack' style English asylums were pointed to as examples of the kind of monotonous architecture that was to be avoided. From the mid nineteenth century onwards it was suggested that an ideal asylum might resemble 'a large English homestead, or some large industrial community', 'a farming or industrial colony', or might be composed of 'separate houses, in which the patients are distributed according to their dispositions and the features and stages of their disease'. Scottish authorities praised Alt-Scherbitz for avoiding the 'monotonous uniformity' of large asylum buildings, implying that 'barracks' architecture rendered the inhabitants dull and passive. Although the barrack style of asylum was also criticised in England, there appears to have been greater resistance than in Scotland to the 'villa system' as an alternative, because of difficulties with 'administration, supervision and cost of maintenance'. ${ }^{57}$ Indeed, after the opening of Kingseat its first medical superintendent concurred with some of these criticisms, saying that a village asylum required a larger staff and was 'perhaps less easy to supervise'..$^{8}$

Howard also understood the city as a source of ill health for specific physical reasons, particularly poor ventilation, smoke, dirt and overcrowding. In this he replicated the 'city as unhealthy' trope put forward by the social explorers, but he also stated that society was 'most healthy and vigorous' where there were free and full opportunities for both individual and combined effort, making perhaps an unconscious elision between physical health and the metaphorical health of society conceived as a growing organism. Howard's conception of health is thus continually associated with his ideas relating to freedom of the individual. Here the assertion of individual freedom allows for a release of 'pent-up energy' which helps society to flourish and releases 'vitality' which is the life force that is suppressed under unequal economic conditions. For Howard, one of the major consequences of social reform along garden city lines was that: 
'A new sense of freedom and joy is pervading the hearts of the people as their individual faculties are awakened, and they discover in a social life, which permits alike of the completest concerted action and of the fullest individual liberty, the long-sought-for means of reconciliation between order and freedom, - between the well-being of the individual and of society'.59

Howard and the asylum builders both saw a healthy and flourishing society as one which promoted individuality, releasing the energy and vitality that was deadened by the monotony and uniformity of asylum materiality and urban slum living alike. Thus the preservation of individuality was noted as a key requirement for sanity by contemporary medical thinkers. The Lancashire Asylums Board concluded in their report on European asylums that 'Individuality is lost in a crowd, and the increasing loss of the sense of individuality in a lunatic goes pari passu with a loss of initiative and of mental energy, in short of mind'. ${ }^{60}$ An asylum organised along 'village' lines could therefore promote mental health by disaggregating patients into small groups and providing an individualising environment which more closely approached a domestic scale. Segregation was not only applied to buildings at Kingseat, but even extended to the choice of furniture: armchairs were chosen which would keep each patient 'isolated' rather than benches seating five or six, which were said to increase patient excitement. Ross has suggested that the second half of the nineteenth century saw an increasing attention to the internal and external spaces of the asylum in an attempt at 'affective engineering', rendering patients more contented and amenable through the attention paid to such details as décor and furnishing. ${ }^{61}$ Individuality was also to be encouraged by variation in building materials, architectural styles and even in the disposition of the buildings within the site, which emphasised irregularity and asymmetry. ${ }^{62}$

\section{CONCLUSION}

In considering whether or not Howard's garden city diagrams provided the template for Kingseat it is important to also consider other potential models for a village asylum layout, particularly in view of 'an international embrace of ... vernacular and asymmetrical forms' which Leslie Topp sees as generative of both the garden city movement and various European asylum layouts. ${ }^{63}$ The builders of Kingseat named 
Alt-Scherbitz as the inspiration they intended to follow, a colony asylum which was causing considerable excitement internationally at the time for its high rate of patient engagement in work, its segregated accommodation and idealised, suburban-style domestic spaces. However, Alt-Scherbitz does not resemble Kingseat in layout, consisting of a series of pavilions arranged in a symmetrical, rectilinear fashion, which housed the acute patients, and a 'colony' for the chronic patients in which the villas follow the irregular form of the river valley along which they are constructed. In other words, the 'closed' portion of the asylum is much more symmetrically structured than Kingseat and the 'open' portion much less so. There are no concentric or radial elements, nor does the site take the shape of a circle sector. Although the villa system was 'universally embraced' in Germany and the Austrian Empire at this period, most examples that were extant in 1900 follow either one or both of the layout elements seen at Alt-Scherbitz. However, Topp also points to another potential inspiration in the form of the Mauer-Öhling asylum, west of Vienna, which followed a strict, symmetrical plan with radial and curved elements amounting to a visual rhetoric, Topp argues, of modernity and rationality. ${ }^{64}$ The Kingseat asylum authorities did not visit Austria in their travels, but they may have been aware of the asylum from journal sources and been drawn to its simplicity and axiality. However, it is argued here that Kingseat shows a closer resemblance to Howard's Diagram No. 3 than to the other available models. Moreover, this spatial similarity is unlikely to have been coincidental given the rising interest in Howard's ideas at the period and the exposure of both Lunacy Board members and the architect to garden city ideals at the Aberdeen Congress of the Royal Institute of Public Health in 190o. The potential parallels between Kingseat and Howard's designs have not previously been the subject of scholarly attention, but this may indicate that the historiographical orthodoxy that correlates late Victorian asylums with 'warehouses' and 'museums of madness' has been too widely embraced. Kingseat and other Scottish asylum designs of the period suggest that, in some geographical regions at least, environment retained its central importance into the early twentieth century despite the challenges raised by some aspects of degenerationist ideology. Kingseat does not fit the historiographical pattern of asylums built merely to sequester, without any thought of therapeutic benefit, nor is it merely a material expression of therapeutic pessimism. 
The 'garden city' at Kingseat should instead be seen as an idealised environment which sought to overcome the besetting issues of working-class housing, the darkness, odours, lack of ventilation, the overcrowded conditions and dirt which affected patients physically and hence morally and mentally. The correlation of the garden city with health was appealing to asylum builders, who sought to avoid the endemic problems of disease and overcrowding presented by the former monolithic style of building. The division of the asylum into a series of separate villas spread out across a rural site was important in preventing the spread of infectious illnesses. The clean air of the countryside was vital for restoring health that had deteriorated in the slum living conditions of the city. However, reformist asylum builders had routinely constructed their buildings in beautiful, elevating (and elevated) surroundings within the 'fringe belt' of cities and towns and surrounded by acres of open space.

Overcrowding could be, and often was, dealt with simply by extending the accommodation already on offer, by constructing additional wings or pavilions connected by corridors onto existing buildings. Alternatively, there were many models of the 'colonization' of institutional space available to the Aberdeen asylum builders including the example that they cited most freely, the colony asylum at AltScherbitz.

If we are to accept that the garden city was the model that was followed at Kingseat this is likely to have been motivated by additional factors. The garden city gave form not only to the marriage of town and country, and to the unity of urban development with health, but also to the wedding of social conformity with liberty and individual freedom with cooperative living. Ebenezer Howard's garden city presented a utopian 'marriage' of a series of opposed concepts, the separation of which troubled the early twentieth-century asylum builder as much as his colleague, the urban social reformer. Howard sought to bring the benefits of society, intellectual stimulation, amusements and plentiful work into the healthy clean air and sunlight of the country. He sought to promote individual freedom within a framework of social cooperation that would benefit all while providing the minimum of restraint, and to release the vitality of the inhabitants by allowing them to benefit from the fruits of their labours and to express their individuality. 
In the same way, asylum builders in Aberdeen were concerned with the insane poor as a herd-like mass whose vitality and individuality were compromised, through bad heredity and/or bad environment. The uniformity and repetitiveness that characterised asylum architecture and furnishings was seen as correlating with a loss of individuality and a consequent loss of vitality and energy that were detrimental to physical and mental health and replicated the repetitiveness and monotony of urban housing and environments. The village asylum made use of the physical arrangement of buildings and spaces to emphasise patient individuality. Howard's garden city design may have been attractive to a professional sector whose faith in the power of environment to be therapeutic was intensifying, underpinned by a resurgence of interest in Lamarckian approaches to evolution based on the inheritance of acquired characteristics, and who were drawn by the utopian resonances of his ideas, seeking, through his forms, to attain a higher level of social functioning for the groups and individuals under their care. Ross has pointed to a refocusing of the 'moral-spatial' logic of asylum care over the second half of the nineteenth century in which environmental innovations, originally applied to acute patients, tended to migrate to incurable, long-stay patients in the hope of achieving both 'curative and calmative' results, and the spatial/symbolic configuration of Kingseat can be seen as fitting within this dynamic. ${ }^{65}$ Additionally, Huxley's 'vitalist' spatial rationality in which environments are shaped in order to 'foster the progressive development of humanity' speaks to asylum space at Kingseat and to garden city spaces, both of which sought to constitute a better humanity through the harnessing of 'vitalistic life forces' that, in both cases, could be released through the spatial disaggregation of bodies. ${ }^{66}$ Despite the spatial exclusion and bodily discipline associated with asylum siting, there is a sense in which the drive to constitute subjects through asylum spaces was focussed as much on inclusion as it was on exclusion. While actually bound, patients were discursively constituted as individualised subjects situated within bourgeois, suburban spaces in which 'freedom' released the vitality which was seen as cohesive to social order. In this, the asylum and the garden city reach an identity of purpose which could account for the choice of garden city as asylum model. 
The apparent rigidity and prescriptiveness of Howard's diagrams led him to draw back from his own schematics over time in favour of an understanding of the garden city that was looser and emphasised the flexibility of his geometrical sketches. If the form of the garden city was replicated at Aberdeen it suggests that the asylum builders were seeking to access, through the planning out of lines and curves, a series of elusive qualities that were not fully entailed by this particular arrangement of constructed buildings, spaces and connecting pathways, but formed part of its symbolic resonance, evoking the idealised society conveyed by Howard in his writings. The division of the traditionally unitary asylum building into a number of separate villas of differing designs, finishes and orientations is emblematic of Howard's marriage of opposites, combining heterogeneity with cohesion. Although the garden city had been proposed by Howard as a solution to the problems of urban overcrowding, disease and unconstrained growth, and not a solution to the problems of a growing asylum population, there were profound similarities in the problems faced by asylum builders and urban reformers and a congruence in the cultural context that gave rise both to the garden city ideal and to idealised asylum spaces.

Howard's work combines a practical economic analysis with some highly evocative writing on the benefits of wedding town with country that include romanticised assessments of the benefits of country living, the beauty of nature and easy access to fields and parks, pure air and water and bright homes and gardens. Howard's understanding of the city as unhealthy was based on well-rehearsed contemporary discourses to which he added ideas of an emotional and spiritual dependency on nature which may have resonated among asylum builders seeking meaningful approaches to designing asylum buildings, spaces and layouts. Howard offered the promise of harnessing the power of the natural environment in favour of good health through the deliberate and planned activity of human beings. His garden city ideal encapsulated the power of environment to influence how people live, think and feel and is unambiguous about the possibility that high quality environments can have powerful effects on both individuals and society. Howard's cultural understanding of health penetrates through the viscerality of bodily illness to deeper perceptions of the nature of mind and spirit, appropriating these as the comforting metaphors of 
successful societal functioning. If asylum builders in Aberdeen did choose Howard's prescription for a better society they would have been allying themselves with a utopian vision of society in which the hope of improvement had not subsided and where therapeutic optimism survived.

\section{NOTES}

\footnotetext{
${ }^{1}$ The Scotsman, 12 th October 1898 .

${ }^{2}$ R.A.M. Stern, D. Fishman and J. Tilove, Paradise Planned: the Garden Suburb and the Modern City, New York, 2013.

${ }^{3}$ For example, the 2014 Wolfson Economics prize asked for a plan for 'a new garden city which is visionary, economically viable and popular'. The winning entry closely referenced Howard, using his 'snowflake' diagram of the Social City to propose a network of 'urban extensions' to an existing town, D. Rudlin and N. Falk, Uxcester Garden City, Manchester, 2014. Although government plans for new garden cities have not materialised, fourteen garden villages are to be built across England with larger garden towns proposed for Buckinghamshire, Somerset and the Essex-Hertfordshire border, The Guardian, 2nd January 2017.

${ }^{4}$ A.T. Scull, Museums of Madness: The Social Organization of Insanity in Nineteenth-Century England, London, 1979.

5 A.T. Scull, Madness in Civilization: A Cultural History of Insanity from the Bible to Freud, from the Madhouse to Modern Medicine, London, 2015, 243-246.

${ }^{6}$ Scull, Museums of Madness, 277-279.

${ }^{7}$ H. Parr, Mental Health and Social Space: Towards Inclusionary Geographies, Oxford, 2008, 13-14

${ }^{8}$ M. Huxley, Spatial rationalities: order, environment, evolution and government, Social and Cultural Geography 7 (2006) 771-787; N. Rose, Powers of Freedom: Reframing Political Thought, Cambridge, 1999, 31-40.

9 C. Hickman, Therapeutic Landscapes: A History of English Hospital Gardens Since 180o, Manchester, 2013; S. Rutherford, The landscapes of public lunatic asylums in England, 1808-1914, unpublished PhD thesis, De Monfort University, 2003.

${ }^{10}$ See H. Richardson, A continental solution to the planning of lunatic asylums 1900-1940, in: J. Frew and D. Jones (Eds), Proceedings of a Symposium held at the University, St Andrews May $19^{\text {th }} 1990$, St Andrews, 1991, 67-79; E.C. Halliday, The hospitalisation of the Scottish asylum 1880-1914, unpublished $\mathrm{PhD}$ thesis, University of Stirling, 2003; A. Darragh, Prison or palace? Haven or hell? An architectural and social study of the development of public lunatic asylums in Scotland, 1781-1930, unpublished PhD thesis, University of St Andrews, 2011 and K.A. Ross, The locational history of Scotland's District Lunatic Asylums, 1857-1913, unpublished PhD thesis, University of Glasgow, 2014 for previous discussion of Kingseat, although none of these writers alludes to the garden city as an influence.

${ }^{11}$ Aberdeen City District Lunacy Board Minutes $19^{\text {th }}$ June 1904, held in Aberdeen Central Library. Although Letchworth is often dated to 1903, no building work was commenced until the summer of 1904. The First Garden City Company Ltd was registered on $1^{\text {st }}$ September 1903 and Parker and Unwin's layout for Letchworth Garden City was issued as 'the company's plan' on $11^{\text {th }}$ February 1904, following a survey of the site in the winter of 1903. See M. Miller, Letchworth Garden City: an architectural view, in: J. Onslow et. al, Garden Cities and New Towns, Hertford, 1990, 48-87. Development of the estate began a few months later, when infrastructure such as roads, waterworks and sewerage were constructed, fifty plots were let and the first houses were started, C.B. Purdom, The Garden City: A Study in the Development of a Modern Town, Letchworth, 1913, 45-46.

${ }^{12}$ Huxley, Spatial rationalities.
} 
${ }^{13}$ P. Hall and C. Ward, Sociable Cities: The $21^{\text {st }}$-Century Reinvention of the Garden City, Abingdon, 2014, 29-35

${ }^{14}$ Howard hoped to finance the building of garden cities by a patented device for variable spacing on typewriters, which was unfortunately rejected by manufacturers, see F.J. Osborn, Sir Ebenezer Howard: the evolution of his ideas, The Town Planning Review 21 (1950) 221-235.

${ }^{15}$ E. Howard, To-morrow: A Peaceful Path to Real Reform, London, 1898, 12-17.

${ }^{16}$ Yorkshire Post, $21^{\text {st }}$ October 1901.

${ }^{17}$ E. Howard, Garden Cities of To-morrow, London, 1902, 22. Most of Howard's original diagrams were dropped from the second edition, leaving only black and white versions of Nos 1, 2 and 3.

${ }^{18}$ Diagram No 2 annotated by Howard in revised volume of To-morrow, Hertfordshire Archives and Local Studies, De/Ho/F4/1, reproduced in M. Miller, English Garden Cities: An Introduction, Swindon, $2010,6$.

${ }^{19}$ Canon S.A. Barnett and S.A. Barnett, The church and town planning, in: Canon S.A. Barnett and S.A. Barnet, Practicable Socialism, London, 1915, 302, quoted in W.L. Creese, The Search for Environment, the Garden City: Before and After, New Haven and London, 1966, 252.

${ }^{20}$ Huxley, Spatial rationalities.

${ }^{21}$ Aberdeen People's Journal, $29^{\text {th }}$ November 1900. The ACDLB visited St Anne and Ville Juif, Paris;

Herzberge, Berlin; Perth and Larbert, Scotland; Rainhill, West Riding, Claybury and Cane Hill, England in addition to Alt-Scherbitz. Many of these hospitals were built as separate pavilions, usually connected by corridors and arranged in a rectilinear or arrow-shaped layout. The exception is Cane Hill where pavilions radiated from a D-shaped core.

${ }^{22}$ The 1898 Annual Report for Aberdeen Royal Lunatic Asylum states that a separate lunacy district for Aberdeen was formed that year. However, no minutes for the new Board have survived prior to $8^{\text {th }}$ November 1901, when building work at Kingseat had already begun. The first Annual Report for Kingseat was produced in 1905 , leaving local newspapers as the principle contemporary source for early events surrounding the construction of the asylum.

${ }^{23}$ Aberdeen People's Journal, $29^{\text {th }}$ July and $12^{\text {th }}$ August 1899.

24 The Aberdeen People's Journal does not record any visits to Aberdeen by Howard, who made his first visit to Scotland to promote garden city ideals in February 1902, see Edinburgh Evening News, $6^{\text {th }}$ February 1902.

${ }^{25}$ Yorkshire Post, $4^{\text {th }}$ January 1900 states that 'A good deal of discussion has been provoked by a proposal of $\mathrm{Mr}$ Ebenezer Howard to found a "garden city" in this country' in relation to a proposed project overseas.

${ }^{26}$ Royal Institute of Public Health, Transactions of the Congress held in Aberdeen, $2^{\text {nd }}$ to $7^{\text {th }}$ August, 1900. London, 1901.

${ }_{27}$ Aberdeen People's Journal, $15^{\text {th }}$ August 1900. Marshall Mackenzie's design for Kingseat is barely acknowledged by biographers and not referenced by obituary writers. The Marshall Mackenzie archive was inherited by John Marr, architects of Inverness, a practice that has subsequently been subsumed and the current whereabouts of the archive is unknown. See R.M. Bailey, C. McKean, D. Walker, I. Gow, I.M. Gray, J. Thomas, Scottish Architects' Papers: A Source Book, Edinburgh, 1996.

${ }^{28}$ An earlier perspective drawing and sketch plan appears in the Kingseat Annual Report for 1904-1905, but this is not attributed to the architect and is imprecise in nature. The 1906 plan is reproduced in a report by Jenkins \& Marr architects for Grampian Healthcare, Kingseat Village Proposals, Aberdeen, 1997 (unpublished report).

29 Howard, To-morrow, 165.

$3^{\circ}$ R. Beevers, The Garden City Utopia: A Critical Biography of Ebenezer Howard, New York, 1988101.

${ }^{31}$ Aberdeen Weekly Journal, $5^{\text {th }}$ December 1900.

${ }^{32}$ Report of a Deputation from the Edinburgh District Lunacy Board, Edinburgh, 1897, 29; E. Godbey, Picture me sane: photography and the magic lantern in a nineteenth-century asylum, American Studies 1 (2000) 31-69; R. Hunter and I. Macalpine, Psychiatry for the Poor: 1851 Colney Hatch Asylum, Friern Hospital 1973, A Medical and Social History, Folkestone, 1974, 56.

33 Scrapbook of newspaper cuttings: National Health Service Grampian Archive, GRHB8/6/2. It is notable that one of the earliest mentions of 'garden city' in the popular magazine The Illustrated London News (1 $3^{\text {th }}$ October 1906$)$ is in connection with another Scottish segregate asylum (at Bangour Village near Edinburgh which did not replicate Howard's layout), suggesting that the association of Scottish asylums of this period with the garden city was made far beyond Aberdeen.. 
34 The early records of the GCA are incomplete, comprising the minutes of AGMs (from 1901), some early pamphlets and the journal The Garden City (1904-1908). Howard's surviving early writings and correspondence likewise contain no allusion to Kingseat, although one of the earliest drafts of his ideas suggests that the 'city of health' would need to attract an institution, namely a home for waifs and strays, in order to bring in capital, population and markets, City of Health and how to build it c18901891, Hertfordshire Archives DE/Ho/F1/5.

35 Reading Mercury, $27^{\text {th }}$ December 1902.

${ }^{36}$ C. Philo, A Geographical History of Institutional Provision for the Insane from Medieval Times to the 1860s in England and Wales, New York, 2004, 430-525.

37 Philo, A Geographical History of Institutional Provision, 2004, 526-650.

${ }^{38}$ H. Freeman, Psychiatry in Britain, c.1900, History of Psychiatry 21 (2010) 312-324; B. Forsythe, Hope and suffering at the Devon county pauper lunatic asylum at Exminster, 1845-1914, Southern History 23 (2001) 116-147; D. Wright, Mental Disability in Victorian England: The Earlswood Asylum 1847-1901, Oxford, 2001, 188-201; P. Fennell, Treatment Without Consent: Law, Psychiatry and the Treatment of Mentally Disordered People since 1845, 1996, 46-50.

${ }^{39}$ M. Jackson, The Borderland of Imbecility: Medicine, Society and the Fabrication of the Feeble Mind in Late Victorian and Edwardian England, Manchester, 2000, 63.

${ }^{40} \mathrm{~J}$. Radford, Sterilization versus segregation: control of the feeble-minded, 1900-1938, Social Science and Medicine 33 (1991) 449-458; J. Radford and D.C. Park, The eugenic legacy, Journal on Developmental Disabilities 4 (1995) 63-74.

${ }^{41}$ Ross, The locational history of Scotland's lunatic asylums, 189-217.

${ }^{42}$ J. Woiak, Drunkenness, degeneration and eugenics in Britain, 1900- 1914, unpublished PhD thesis, University of Toronto, 1998, 30-71; S. Snelders, F.J. Meijman and T. Pieters, Heredity and alcoholism in the medical sphere: The Netherlands, 1850-1900, Medical History 51 (2007) 219-236.

43 The term 'psychiatrist' is used here for clarity, but 'alienist' was usually preferred by the medical profession at this period. Clouston was physician superintendent of Edinburgh Royal Asylum from 1873, the first official lecturer in mental diseases at the University of Edinburgh between 1879 and 1908, president of the Medico-Psychological Association, editor of the Journal of Mental Science and writer of numerous publications on mental illness including Clinical Lectures on Mental Diseases which went through six editions and had an influence that was felt far beyond Edinburgh. See A. Beveridge, Thomas Clouston and the Edinburgh school of psychiatry, in: G.E. Berrios and H. Freeman (Eds), 150 Years of British Psychiatry, 1841-1991, volume 1, London, 1991, 359-388

44 T.S. Clouston, The Hygiene of Mind, London, 1906, 64.

45 Clouston, The Hygiene of Mind, 56. Clouston later appeared to advocate sterilization of the 'unfit', but nonetheless retained a belief in the power of environment to affect mental health, see T.S. Clouston, Unsoundness of Mind, London, 1911, 296, 320.

${ }^{46}$ Clouston, Unsoundness of Mind, 94.

47 W.P. Letchworth, The Insane in Foreign Countries, New York, 1889, 313-330.

${ }^{4}$ T.S. Clouston, Clinical Lectures on Mental Diseases, London, 1898, 688-689.

49 Howard, To-morrow, 32.

$5^{0}$ The Manchester Guardian, $2^{\text {nd }}$ March 1904. Howard and Clouston may well have met in November 1903 when Howard made a second tour of Scotland to promote the garden city, and they certainly met in 1908 when Clouston was present at a meeting to constitute the Edinburgh and East of Scotland branch of the Garden City Association at which Howard spoke, see The Scotsman, $25^{\text {th }}$ November 1908. ${ }^{51}$ Ross, The locational history of Scotland's lunatic asylums, 307-308.

${ }^{52}$ M. Foucault, Discipline and Punish: The Birth of the Prison, New York, 1977.

53 A.T. Scull, The Most Solitary of Afflictions: Madness and Society 1700-1900, New Haven and London, 1993,325 .

54 Councillor W. Cooper, An ideal workman's cottage, in: Proceedings of the Congress of the Royal Institute of Public Health 190o, 456-462. The attempts of Matthew Hay, Medical Officer of Health for Aberdeen, to improve housing conditions and clear slums in this period are summarised in N.J. Williams, Housing, in: W.H. Fraser and C.H. Lee (Eds), Aberdeen 180o-20oo: A New History, East Lothian, 2000, 295-322.

55 J. Taylor, Hospital and Asylum Architecture in England, 1840-1914: Building for Health Care, London, 1991, 133-155.

${ }^{56}$ Copy of the Fiftieth Report of the Commissioners in Lunacy to the Lord Chancellor, London, 1896. 
57 G. Allmond, Liberty and the individual: the colony asylum in Scotland and England, History of Psychiatry 28 (2017) 29-43; J. Taylor, The architect and the pauper asylum in late nineteenth-century England: G T Hine's 1901 review of asylum space and planning, in: L. Topp, J.E. Moran and J. Andrews (Eds), Madness, Architecture and the Built Environment: Psychiatric Spaces in Historical Context, New York, 2007, 263-284.

${ }^{8}$ ACDLB Annual Report 1907, NHS Grampian Archive, University of Aberdeen Special Collections, GRHB8/6/1.

59 Howard, To-morrow, 143.

${ }^{60}$ Report of a Deputation Appointed to Visit Asylums on the Continent with Recommendations Regarding the Building of a New (Sixth) Lancashire Asylum, Preston, 1900.

${ }^{61}$ Ross, The locational history of Scotland's lunatic asylums, 269-277.

${ }^{62}$ Allmond, Liberty and the individual; H.J. Blanc, Bangour Village asylum, RIBA Journal 15 (1908) 309326.

${ }^{63} \mathrm{~L}$. Topp, Psychiatric institutions, their architecture, and the politics of regional autonomy in the Austro-Hungarian monarchy, Studies in History and Philosophy of Biological and Biomedical Sciences 38 (2007) 733-755.

${ }^{64} \mathrm{~L}$. Topp, The modern mental hospital in late nineteenth-century Germany and Austria: psychiatric space and images of freedom and control, in: Topp, Moran and Andrews (Eds), Madness, Architecture and the Built Environment, 241-262.

${ }^{65}$ Ross, The locational history of Scotland's lunatic asylums, 306-310.

${ }^{66}$ Huxley, Spatial rationalities. 